\title{
Orally Disintegrating Delayed Release Tablet Dosage Form
}

National Cancer Institute

\section{Source}

National Cancer Institute. Orally Disintegrating Delayed Release Tablet Dosage Form.

NCl Thesaurus. Code C61006.

A tablet that disintegrates rapidly, usually within a matter of seconds, when placed upon the tongue but is also designed to impede the immediate release of the active and/or inert ing redient(s) after administration. 